\title{
Innovative earthquake resistant timber-glass buildings
}

\author{
Bostjan Ber ${ }^{1}$, Miroslav Premrov ${ }^{2}$, Iztok Sustersic ${ }^{3}$, Bruno Dujic $^{3}$ \\ ${ }^{1}$ Kager Hisa d.o.o., Ptuj, Slovenia \\ ${ }^{2}$ Faculty of Civil Engineering, University of Maribor, Maribor, Slovenia; ${ }^{*}$ Corresponding Author: miroslav.premrov@um.si \\ ${ }^{3}$ Contemporary Building Design, Celje, Slovenia
}

Received 13 June 2013; revised 13 July 2013; accepted 20 July 2013

Copyright (C) 2013 Bostjan Ber et al. This is an open access article distributed under the Creative Commons Attribution License, which permits unrestricted use, distribution, and reproduction in any medium, provided the original work is properly cited.

\begin{abstract}
Over the past decade the use of large size glazing has increased with timber structures. Most of the research works done so far have focused on the building physics aspects of the glazing. This paper, however, deals with the seismic behaviour of timber-glass systems. A series of experiments were performed on the shaking table of the IZIIS institute in Skopje, Macedonia. One- and two-story full scale structures were subjected to a series of ground motions, namely sinus sweep testing, natural and modified ground motion accelerograms. All together 8 different setups were tested in elastic and inelastic behaviour range. Displacements and accelerations were measured in each floor as well as the slipping of walls, uplifting of their corners and the shear deformation of the adhesive between the glass panels and the timber frames. The tested combination of timber-glass walls exhibited a rocking type of behaviour, resulting in a desirable ductile failure of steel hold-downs and not brittle failure of the glazing nor failure of the adhesive. Hence such a combination of glass and timber in wall systems could potentially be used in seismically active areas.
\end{abstract}

Keywords: Timber; Glass; Seismic; Shake Table Testing; Experimental Mechanics

\section{INTRODUCTION}

The use of timber in today's contemporary housing is increasing. It is a desirable building material due to its low self-weight and high strength, hence making it especially suitable for seismically active areas. It is also an ideal construction material from the perspective of envi- ronmental impact and energy efficiency as it has very low heat transmission, stores carbon dioxide and needs very little energy for processing. Namely just the $\mathrm{CO}_{2}$ emissions in the processing of timber are approximately two times lower that those present in manufacturing an equivalent masonry element, three times lower than in the case of a concrete element and six times lower than emissions in steel element production. In addition one cubic metre of timber (during growth) can store about two tonnes of $\mathrm{CO}_{2}$, which no other building material is capable of. Due to its properties timber walls can be thinner than conventional walls from concrete or masonry and allow for a high degree of prefabrication, hence speeding up the construction process.

On the other hand the use of glass as a building material is still rather new. It has been extensively used for a longer period in the form of builder's joinery, namely doors, partition walls, fences, facades etc. However the concept of using glass for the main load bearing elements, i.e. beams and columns, is rare. This is due to several reasons, from the lack of building codes on one end to the psychological effect of perceiving glass as a fragile material on the other. The demand for the use of glass in architecture is increasing though and several studies have been performed over the past decade [1-12] to investigate the possibilities of using glass for load bearing elements; either as a standalone material or in combination with other materials.

In this paper we present the concept of using glass as a horizontal seismic bracing element of timber frames. Motivation, design concept and test results of shaking table tests are presented in the following chapters.

\subsection{Building Physics Concept}

The design of modern houses is orientated towards a high living quality and low energy consumption. Today the architects are forced to orientate a house and its 
transparent areas so that it makes the best use of natural solar incomes. The latter is preconditioned by an appropriate size and orientation of the transparent areas, which have to transmit an adequate amount of solar energy into a building in order to assure natural lighting and heating of interior space. Comparing transmission losses through the building's envelope and possible solar gains through the glazing is of great importance to define the optimal size of glazing areas and a suitable selection of glazing type.

Respecting the aforementioned facts, the largest area of the glazing in a building has to be orientated towards south (for buildings in the northern hemisphere) [13]. Such placement of large glass areas (Figure 1) enables better energy performance of a building, where the daily obtained solar gains through the glazing can be evidently higher than the transmission losses through these same glazing areas throughout the night.

At the same time, however, this unfortunately leads to specific technical challenges regarding the structural behaviour of load bearing elements where the enlarged size glazing is installed. This kind of construction systems can be, despite their energy efficiency, very problematic when a building is horizontally loaded.

\subsection{Seismic Behaviour}

Two typical horizontal load cases on a building are wind and earthquake. Their load distributions over the building height are somewhat similar although their effect on the building and their consequences are different. Wind forces apply pressure on the outer walls of the building, both pressure on the windward side and suction on the leeward side. The global resultant of wind forces of a building depends on its shape, regardless of the building material. The seismic forces, however, affect the building proportional to its mass distribution over the floor plan and height as well as the stiffness distribution of the buildings horizontal bracing elements (walls or frames). For a majority of buildings on seismically active

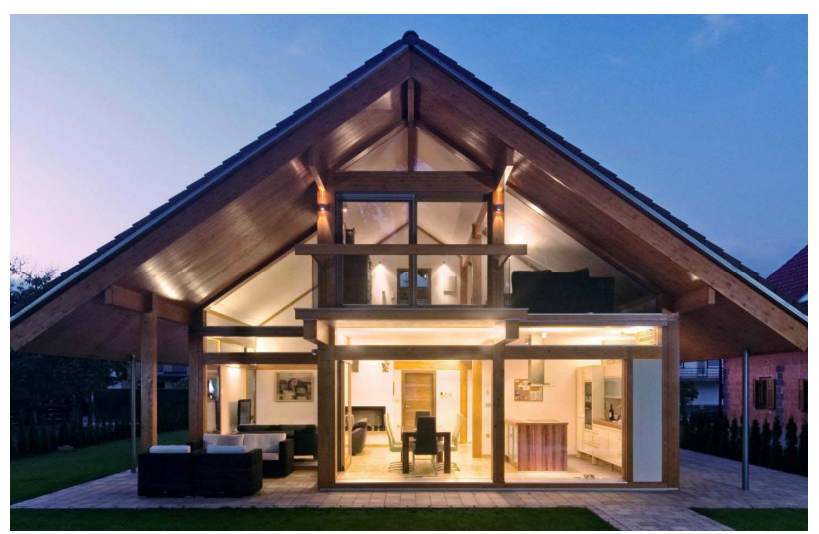

Figure 1. Large size glazing on the southern facade. areas the more problematic of the two is earthquake, which subjects a building to a high intensity dynamic load often resulting in catastrophic consequences. The general principle when designing a building to resist earthquakes is to take into account a certain level of damage allowed to develop on structural elements during an earthquake. As long as the story drifts are kept within limited values the damage is allowed as it enables seismic energy dissipation. However this damage may only occur in elements that behave ductile, hence do not fail brutally. This is the complete opposite to the general behaviour of glass, which is a strong, yet brittle material. Hence the timber-glass building should be either designed strong enough to withstand the seismic forces undamaged or the glass elements should be protected against too high forces by connecting it to the main structure using ductile fasteners. Both principles are described more in detail in the following chapters.

Another basic principle when designing a building to resist seismic loads is trying to avoid plan irregularity. This means that the building's centre of mass and centre of stiffness should be close together, hence avoiding the unfavourable effects of torsion. Unfortunately, this is an issue concerning energy efficient buildings that have large glazing areas predominantly placed on southern facades, hence resulting in an uneven stiffness over their floor plan. As demonstrated in Figure 2 the centre of mass is usually located about in the centre of a building.

The centre of stiffness, however, is placed closed to the stiffer wall elements. As the centre of mass will yaw around the centre of stiffness it will cause higher story drifts on the glazing side causing an uneven distribution of forces over the building's floor plan. Hence the aim of

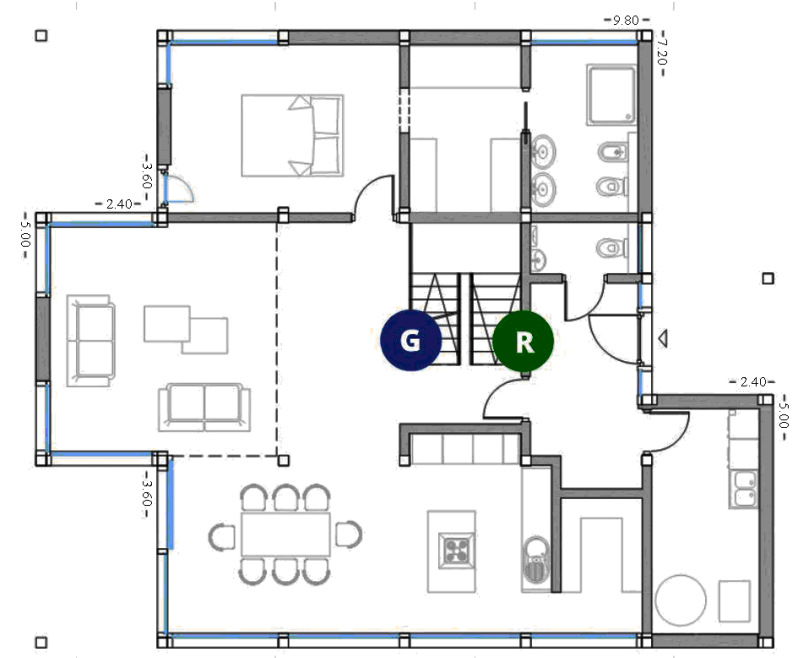

Figure 2. Centres of mass (G) and of stiffness (R) do not coincide in a structure with stiffer walls on one side and more flexible frames on the other, hence causing a torsional behaviour of a building. 
this study was to investigate the possibility of using glass panels as part of the façade's glazing, to resist horizontal loads caused by an earthquake.

\section{WALL ELEMENTS}

The main systems for resisting horizontal loads in buildings are either walls or moment resisting frames. Their behaviour is different for different boundary conditions (geometry, vertical load on the structure, anchoring etc.) and materials. Masonry and concrete walls of course behave differently from timber walls, however all timber walls do not behave in the same way as well. Various systems are described more in detail in the next chapter.

\subsection{Timber Load Resisting Systems}

There are various timber load resisting systems available for building construction as demonstrated in Figure 3. These systems resist both vertical and horizontal loads. However they all resist horizontal loads using different principles for dissipating seismic energy. Bellow we only describe the light timber frame system also used in the experimental testing.

The light timber frame-panel wall system, analysed in this research, originates from the Scandinavian-American construction methods where assembly work takes place on-site. However the wall elements with a total length of up to 12.5 meters are now entirely factoryproduced. Single wall panels are typically $1250 \mathrm{~mm}$ wide and $2500-3100 \mathrm{~mm}$ high. They consist of a timber frame (that resists the vertical load) and sheets of boardmaterial fixed by mechanical fasteners to one or both sides of the timber frame. The sheathing resists the horizontal loading. It is made from either oriented strand board (OSB), plywood or even gypsum-fibre board. Fasteners that fix the sheeting to the frame (usually staples or nails) must ensure a ductile failure mechanism also enabling energy dissipation. Due to a large number of such small fasteners such systems can dissipate a lot of seismic energy, hence making them very earthquake efficient. Design methods for such systems have been developed [14-17] however the European design codes still do not offer any detailed seismic design guidance. On the other hand other design standards, like the New Zealand timber standard [18] provide methods for calculating the exact stiffness of such walls based on several parameters and taking into account various boundary conditions.

\subsection{Glass Walls Concept}

Combining timber and glass to get an appropriate load-bearing element is a challenging process. We are combining two materials with rather different characteristics. Namely, the external timber-glass wall elements

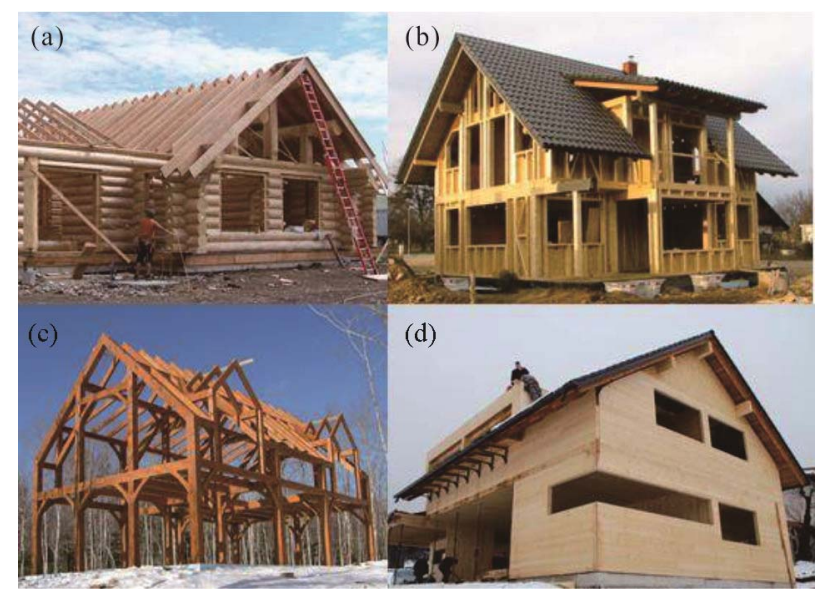

Figure 3. Different timber load resisting systems; log house (a); light timber frame (b); post and beam (c); massive cross laminated timber panels $(\mathrm{d})$.

will be mostly placed in the south. Hence, they will be exposed to high temperature differences. Unfortunately, the coefficients of thermal linear expansion $\left(\alpha_{t}\right)$ of timber and glass are quite different (almost a factor of two in the grain direction). Perpendicular to the grain, the coefficient of thermal expansion for timber is as much as ten times larger than the coefficient parallel to grain, Hoadley [19]. That is almost twenty times lower than for glass. Consequently, temperature differences can cause high shear stresses in the adhesive between the timber frame and the glass panels.

There are numerous parameters, which influence the horizontal resistance and stiffness of the timber-glass wall elements, i.e. material properties and thickness of glass panes. However, the connection between timber and glass is one of the most important. The following connection parameters have a significant influence on the response of timber glass walls (if the glass is glued to timber): 1) the position of the glass pane and hence the position of the glue line; 2) the type of the adhesive and 3 ) the thickness and width of the glue line.

The aforementioned parameters have been studied by several authors; Niedermaier [1], Kreuzinger \& Niedermaier [2], Holzforshung Austria [3], Cruz et al. [4], Blyberg [5], Ber et al. [6] and Schober [7] experimentally and numerically as well.

As discussed in chapter 1.2 one of the possibilities for using a fixed glazing in prefabricated timber-frame panel wall elements is to replace the classical sheathing boards with the glass panes (as schematically presented in Figure 4). The glass panes need to be sufficiently overstrengthened (relative to the metal fasteners that connect them to the timber frame) to ensure that a ductile failure mechanism forms in the connection between the glass and the frame.

However the other option is to connect the glass pan- 
els to the main timber frame without the use of ductile fasteners (using an adhesive instead) and to sufficiently dimension the glass panels to resist the seismic forces in an elastic state.

This is not the standard-recommended approach as it can still result in brittle failure however several timber house producers already install their glazing using such a principle. They do use other design principles of resisting the horizontal load (i.e. installing moment resisting frames around the glass panes). So far, the contribution of the glass to lateral resistance and stiffness of the timber-frame wall elements has been neglected. However the glass panes have a substantial influence of the buildings behaviour. Hence, analysing the behaviour of such panels was the main aim of our experimental study.

\section{EXPERIMENTAL ANALYSIS}

So far a number of studies on combining glass with timber were performed, some of them also focused on the in-plane load-bearing capacity of glass panes [1-7, $11,12]$. However, the research presented in the following chapters was not limited to investigating the in-plane load-bearing capacity of glass panes under a monotonic or cyclic static load. The experimental testing was focused on the load-bearing capacity of one- and two-story timber-glass buildings under a dynamic shaking table induced load.

\subsection{Test Wall Specimens}

Timber-glass wall elements consisted of timber frames with the outside edges measuring $2.4 \times 2.4 \mathrm{~m}$, which is a standard size for testing the racking strength of light timber frame wall panels according to EN 594 [20]. Dimensions of timber stud cross sections were 160/160 $\mathrm{mm}$. The dimensions of the top beam cross section (width/height) were $80 / 280 \mathrm{~mm}$ and the dimensions of

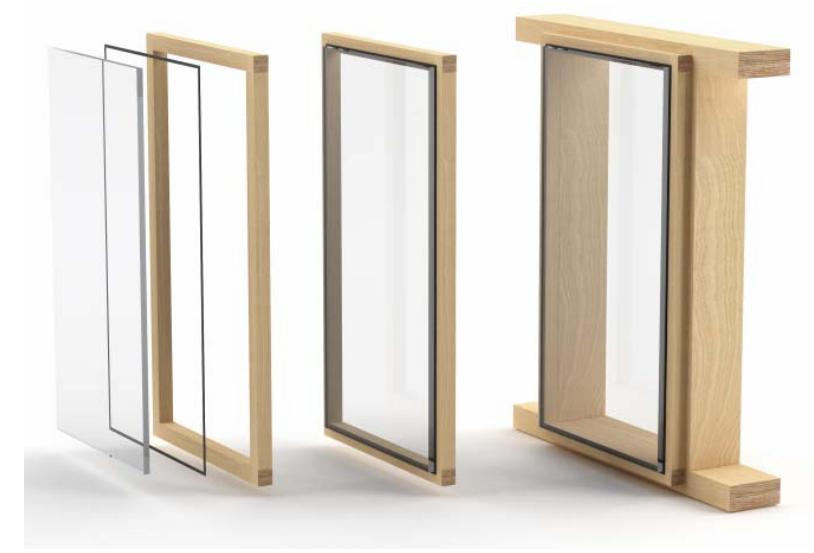

Figure 4. Timber-glass prefabricated walls; replacing classical sheathing boards with glass panes. the bottom sill were $160 / 120 \mathrm{~mm}$. The isolative glass panels were made from three $6 \mathrm{~mm}$ glass panes. The adhesive layer made from one-component polyurethane was $5 \mathrm{~mm}$ thick.

Timber frames were made of GL24 h grade timber according to EN 1194 [21]. Triple insulation glass panes were made of float glass and the adhesive used in the timber-glass joint was a one-component polyurethane adhesive, type Ködiglaze $\mathrm{P}$ produced by Kömmerling. The material properties of float glass were taken from EN 572-1 [22], and material properties of adhesives were obtained from the producer's technical sheet [23]. All material properties are listed in Table $\mathbf{1}$ and the adhesive stress-strain curve is presented in Figure 5.

Light timber frame wall elements with OSB sheathing were also used with the tested specimens. They consisted of a timber frame and $12 \mathrm{~mm}$ thick OSB sheathing stapled onto the timber frame. Dimensions of timber studs, top and bottom sills were 80/100 $\mathrm{mm}$. Four different walls types were used for the assembly of the tested specimens (Figure 6). "TGWE1" represents a timber frame with one large glass panel. "TGWE2" represents a timber frame with two smaller glass panels divided by an additional stud in the middle. "LTFWE1" represents a large timber frame wall element with two OSB sheathing

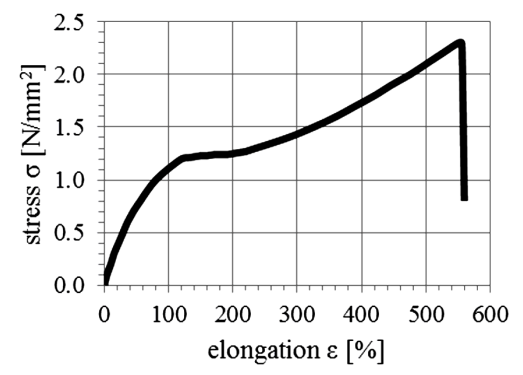

Figure 5. Stress-strain diagram of onecomponent polyurethane adhesive.

Table 1. Properties of the materials used.

\begin{tabular}{ccc}
\hline & Timber frame GL24 h & Float glass EN 572-1 \\
\hline $\begin{array}{c}E_{0, m} \\
{\left[\mathrm{~N} / \mathrm{mm}^{2}\right]}\end{array}$ & 11,600 & 70,000 \\
$G_{m}$ & & \\
{$\left[\mathrm{~N} / \mathrm{mm}^{2}\right]$} & 720 & 28,455 \\
$f_{m, k}$ & & \\
{$\left[\mathrm{~N} / \mathrm{mm}^{2}\right]$} & 24 & 45 \\
$f_{t, 0, k}$ & & \\
{$\left[\mathrm{~N} / \mathrm{mm}^{2}\right]$} & 16.5 & 45 \\
$f_{c, 0, k}$ & & \\
{$\left[\mathrm{~N} / \mathrm{mm}^{2}\right]$} & 24 & 500 \\
$\rho_{k}$ & 380 & 2500 \\
{$\left[\mathrm{~kg} / \mathrm{m}^{3}\right]$} & & \\
\hline
\end{tabular}




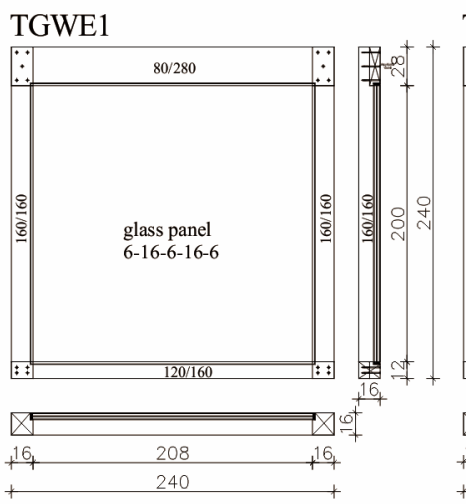

TGWE2

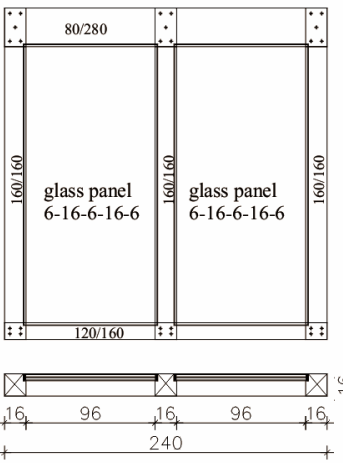

LTFWE1

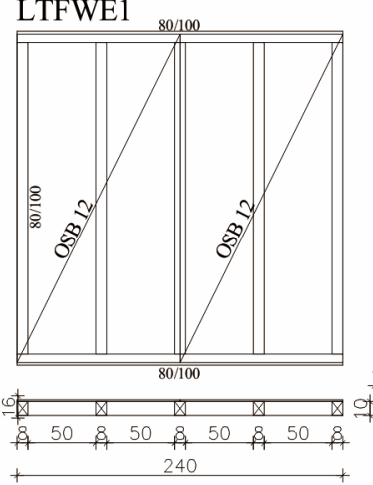

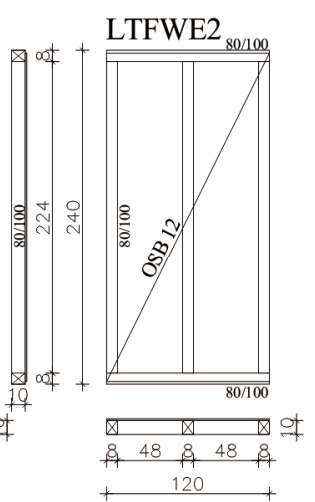

Figure 6. Dimensions of timber-glass and light timber frame wall elements.

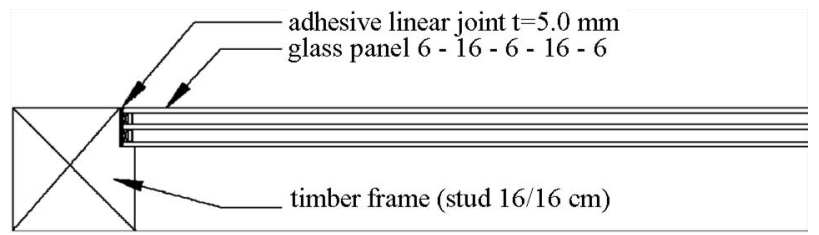

Figure 7. The connection detail between the timber frame and the glass panel.

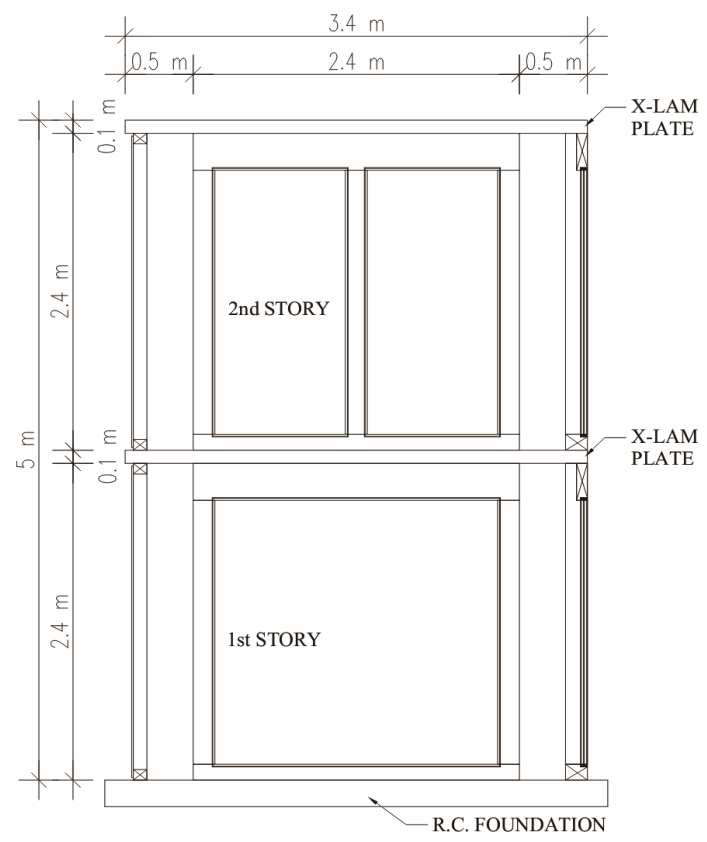

Figure 8. Dimensions of one- and two-storey test models.

boards (installed from one side) measuring $2.4 \times 2.4 \mathrm{~m}$ while "LTFWE2" represents a small timber frame wall element with one OSB sheathing board measuring $1.2 \times$ $2.4 \mathrm{~m}$.

A special connection detail (Figure 7) was used to bond the timber frames and the glass panels together. A $50 \mathrm{~mm}$ wide and $5 \mathrm{~mm}$ thick adhesive layer was applied circumferentially around the glass panel into a groove in the timber frame. The choice of the adhesive and the glass type, was based on the test results of previously done monotonic static tests of glass-timber panels with single pane glazing [6].

\subsection{Test Building Configurations}

Four single-storey and four two-storey structures combining different types of wall elements with ground plane dimension of $2.4 \times 3.4 \mathrm{~m}$ were tested on the shaking table. $100 \mathrm{~mm}$ thick cross laminated (XLam) timber floor slabs were used and an additional mass of $1600 \mathrm{~kg}$ was installed on every floor. Single-storey setups had a total height of $2.5 \mathrm{~m}$, two-storey setups reached exactly 5 $\mathrm{m}$ in height (Figure 8). It should be noted however that the XLam slabs were transferring a majority of the vertical load of the floor onto the walls perpendicular to the excitation direction. The walls loaded in plane hence had minimal vertical load applied on top. That is an important boundary condition that affects the seismic behaviour of the respective walls.

Wall elements were anchored with hold-downs WKR 285 in the corners (Figure 9) and with shear angular brackets WKR 135 installed at every $800 \mathrm{~mm}$ (centre to centre) along the bottom sill. The floor plates were connected to the bottom walls with self-tapping $8 \mathrm{~mm}$ diameter screws (180 mm long) at a distance of $150 \mathrm{~mm}$ centre to centre. Top and bottom walls were vertically anchored by hold-downs in the corners with $12 \mathrm{~mm}$ diameter bolts (Figure 9). The upper walls were also connected to the floor slab with shear angular brackets. The latter were fixed to the slab using self-tapping screws.

Various combinations of one- and two-story structures were tested (Figures 10, 11) by combining different wall setups; namely large and small glass panes and combining LTF and TGW walls to elicit torsional behaviour of the building. Four accelerometers and two potentiometers were placed in each floor for measuring the accelera- 


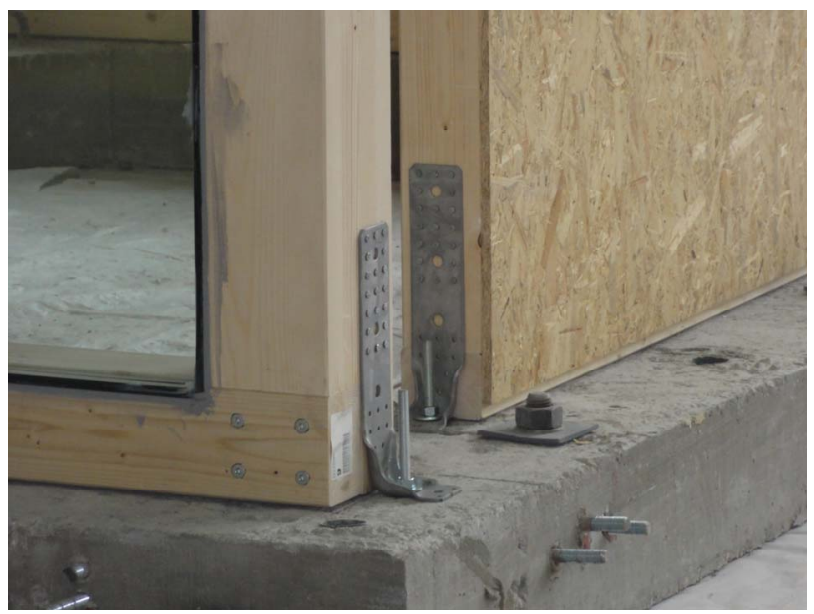

(a)

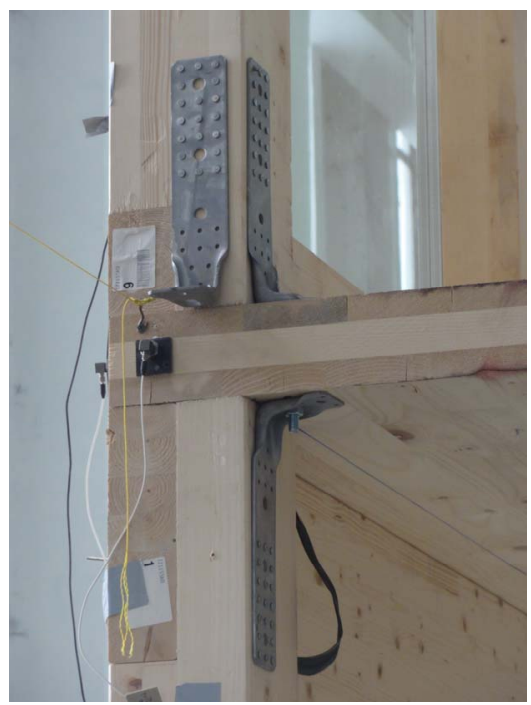

(b)

Figure 9. Steel hold-downs placed in the corners of walls in the ground floor and anchored into the RC foundation (a) and the vertical anchoring between wall panels of the ground and first floor (b).

tions in all directions and displacements in the excitation direction. To analyse the failure mechanisms setups GLS5 and GLS10 had additional instrumentation for measuring slips in the connection planes (timber-timber and timber-glass) and the uplifting of wall corners installed.

\subsection{Loading Protocol}

The testing series was divided into two basic modules; 1) low-intensity testing where the structure remained undamaged and in an elastic state of the material behaviour (including all the connections) and 2) high-intensity testing where the ground acceleration was scaled up enough to cause failure in the structure. Before and after

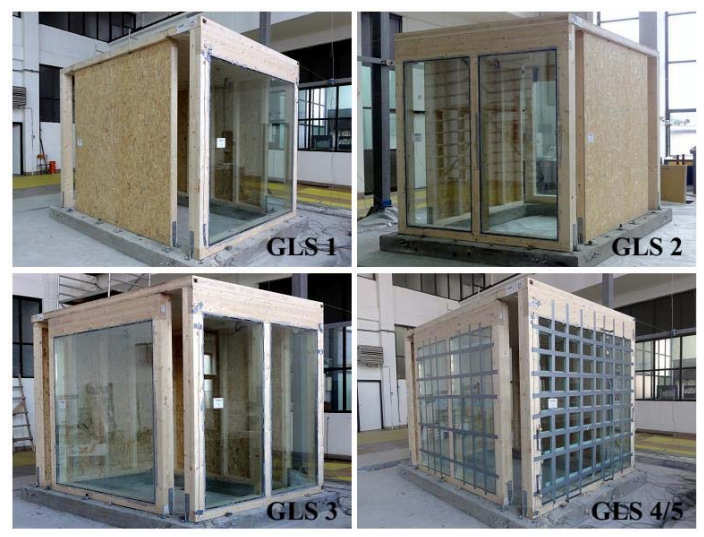

Figure 10. Configuration of one-story test models.

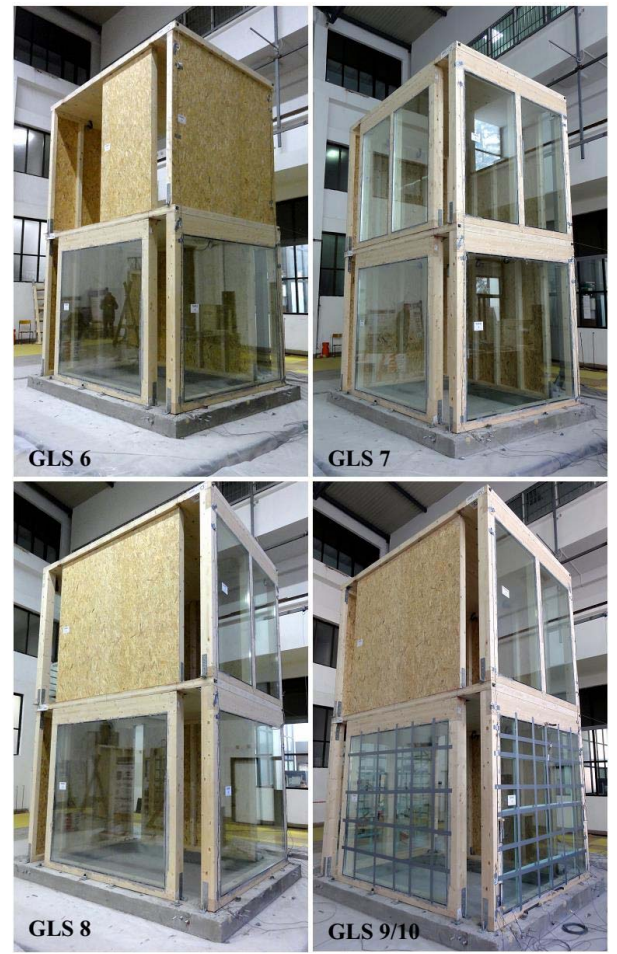

Figure 11. Configuration of two-story test models.

each earthquake simulation a sine sweep test (frequencies in the range of $1-32 \mathrm{~Hz}$, acceleration intensity of $0.01 \mathrm{~g})$ was performed in order to clearly calculate the vibration period of the structure. The sinus test was followed by a series of scaled modified accelerograms of the Landers earthquake.

The accelerogram was modified in a way to excite a broad spectrum of vibration periods namely to affect all types of structures regardless of their stiffness as shown on the comparison of the accelerogram's elastic spectra (with 5\% damping) to the standard Eurocode 8 elastic spectra in Figure 12. In addition to the modified scaled Landers accelerogram also sine-beat loads were applied 


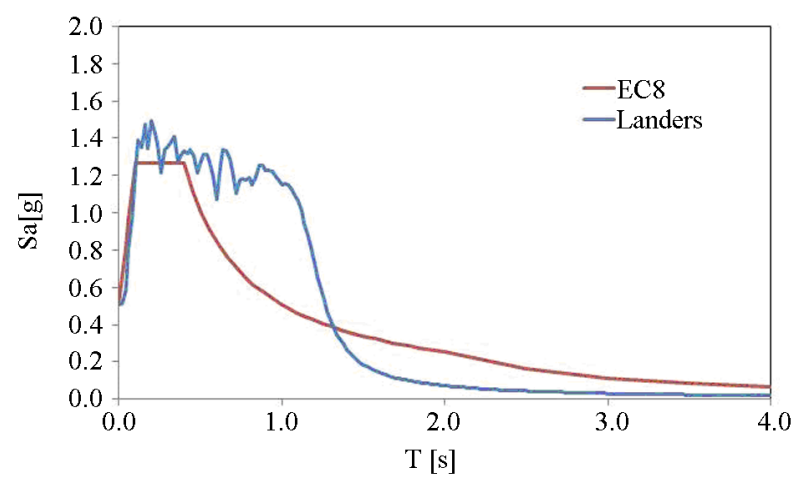

Figure 12. Comparison of the elastic response spectra of the modified Landers accelerogram and the standard Eurocode 8 spectra, both with $5 \%$ damping.

Table 2. The applied loading protocol.

\begin{tabular}{cc}
\hline \multicolumn{2}{c}{ Low-intensity testing } \\
\hline GLS1-GLS4 and GLS6-GLS9 \\
modified Landers & $0.15 \mathrm{~g}$ \\
modified Landers & $0.25 \mathrm{~g}$ \\
Petrovac & $0.22 \mathrm{~g}$ \\
\multicolumn{1}{c}{ High-intensity testing } \\
modified Landers & GLS5 \\
modified Landers & $0.50 \mathrm{~g}$ \\
sine-beat 9.856 Hz & $0.75 \mathrm{~g}$ \\
sine-beat 9.856 Hz & $0.10 \mathrm{~g}$ \\
sine-beat 9.856 Hz & $0.50 \mathrm{~g}$ \\
random 2 - 15 Hz & $1.00 \mathrm{~g}$ \\
random 2 - 15 Hz & $0.10 \mathrm{~g}$ \\
random 2 - 15 Hz & $0.25 \mathrm{~g}$ \\
modified Landers & $0.40 \mathrm{~g}$ \\
modified Landers & \\
random 2 - 15 Hz & $0.50 \mathrm{~g}$ \\
random 2 - 15 Hz & $0.75 \mathrm{~g}$ \\
\hline
\end{tabular}

to the one-story structure. Namely 3 single-beats at 9.856 $\mathrm{Hz}$ (the 1st vibration frequency of the tested structure configuration) scaled up to $0.40 \mathrm{~g}$. They were followed by a randomly generated varying $(2-15 \mathrm{~Hz})$ sinus ground motion scaled up to $0.40 \mathrm{~g}$ for one-story and up to $0.35 \mathrm{~g}$ for two-story specimens. The whole list of applied ground motions is specified in Table 2.

For the low-intensity testing also the Petrovac accelerogram was used. However for the high intensity testing also sine-beats with the first frequency of the structure were applied as well as random sinus tests with frequencies raging in the from 2 to $15 \mathrm{~Hz}$. The results are discussed in the next chapter.

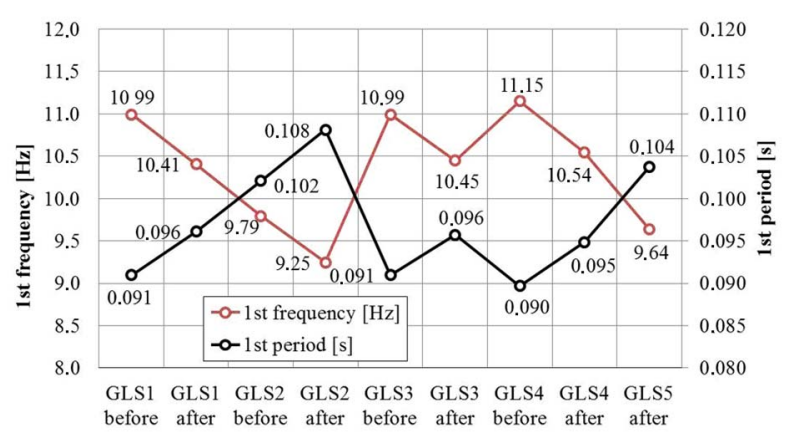

Figure 13. Vibration periods for one-story models.

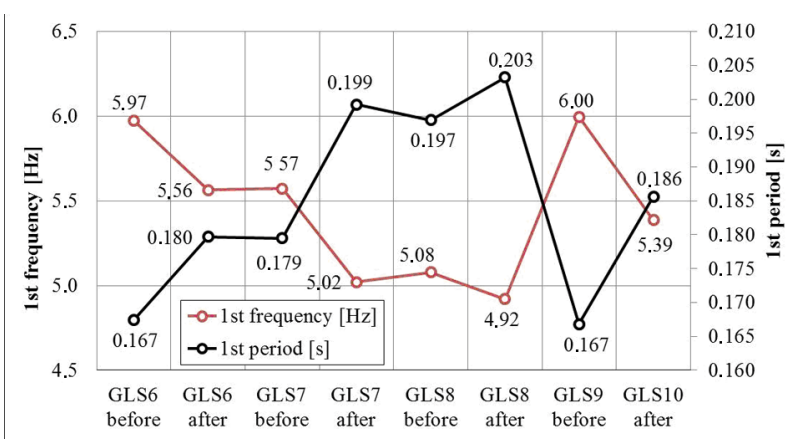

Figure 14. Vibration periods for two-story models.

\subsection{Results and Discussion}

Diagrams of first frequencies and first periods are shown in Figures 13 and 14.

After being subjected to the recorded (Petrovac) and modified (Landers) accelerograms the structures did not exhibit any serious damage. To intensify the response of the structure a randomly generated ground motion with the frequency range of $2-15 \mathrm{~Hz}$ peak ground acceleration up to $0.4 \mathrm{~g}$ was applied. Deformations in the adhesive joint between the glass panel and the timber frame as well as slip of the entire timber frame and uplift at the corners were visible. They are presented in Figure 15 for the specimen GLS10 and the random excitation with a $0.35 \mathrm{~g}$ peak acceleration.

During the high-intensity testing the walls exhibited a rocking-type of behaviour with uplifting at the corners $(0.6$ to $0.8 \mathrm{~mm})$ and minor slip of the walls in the ground floor $(0.15$ to $0.2 \mathrm{~mm})$. Most of the seismic energy was dissipated in the steel connections without any damage in the glass. A shear slip of 1 to $1.5 \mathrm{~mm}$ was present in the adhesive between the glass panel and the timber frame, however seal remained undamaged.

The timber-glass walls have 5 theoretically possible failure modes (Figure 16) when loaded in-plane: (1) failure of corner hold-downs; (2) failure of shear brackets; (3) failure of the adhesive joint between glass and timber; (4) failure of the glass panel and (5) failure of the columns. The tested walls demonstrated a desirable rock 


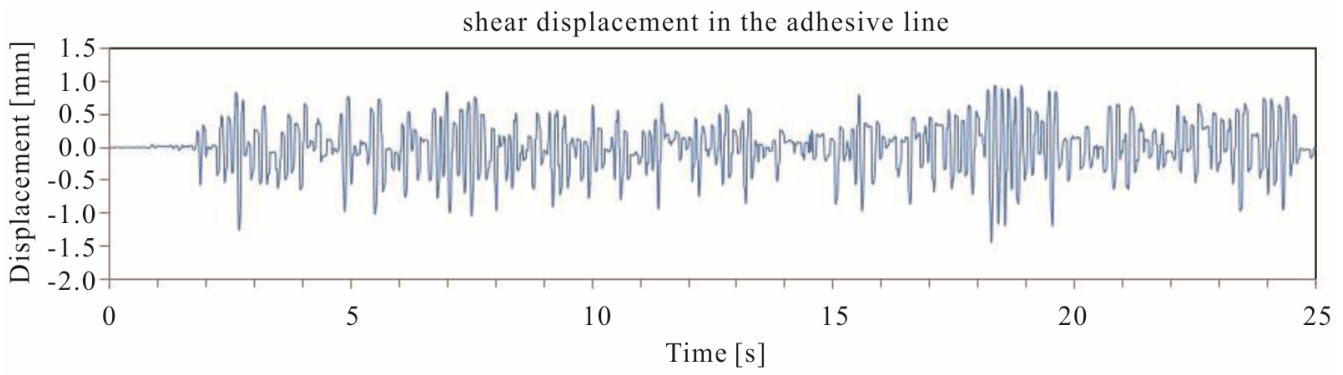

(a)

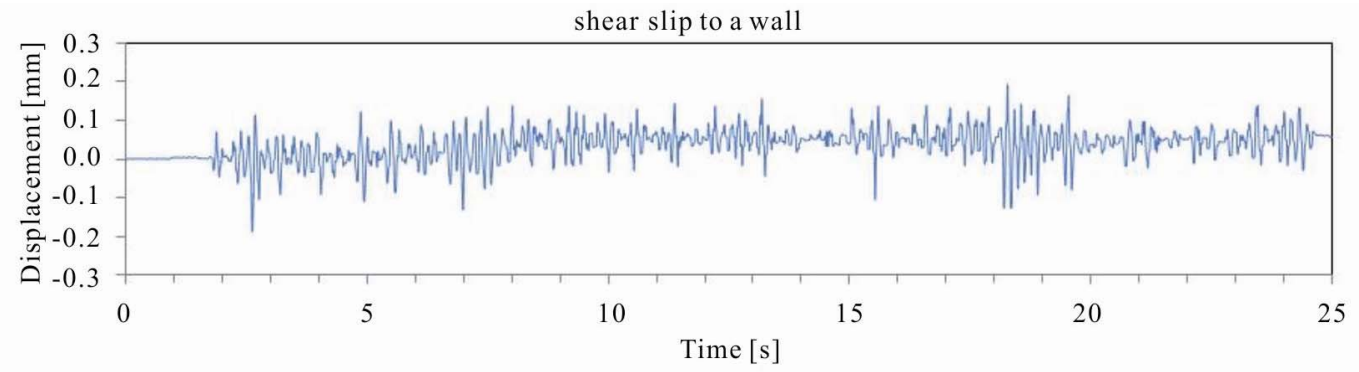

(b)

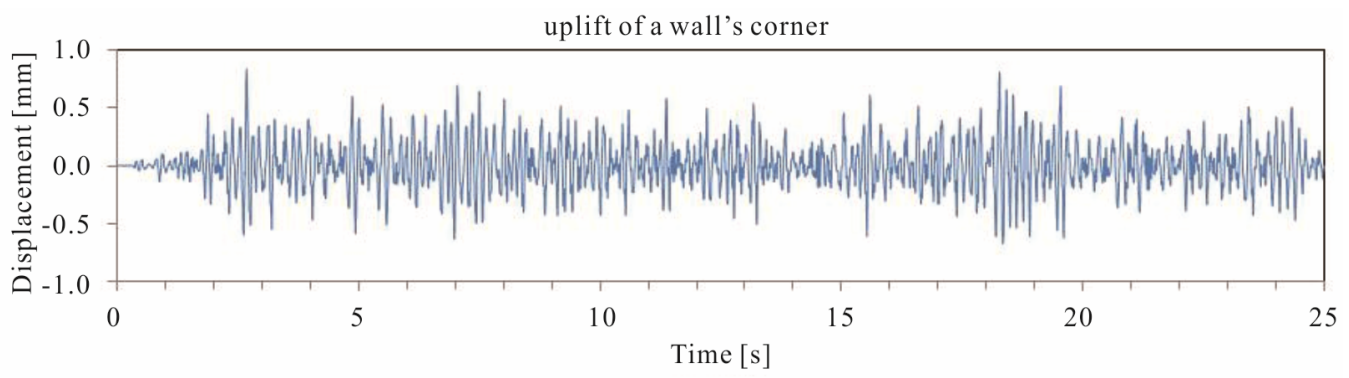

(c)

Figure 15. LVDT measurements of the shear displacement in the adhesive line between timber and glass (a), shear slip of a wall (b) and corner uplift of a wall (c).

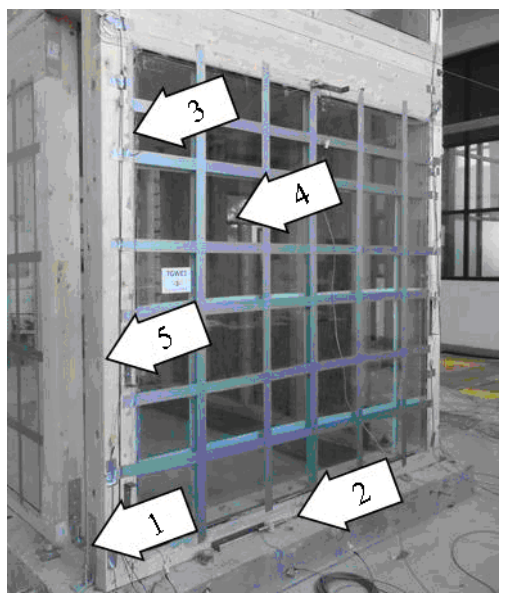

Figure 16. Theoretically possible failure modes; mode (1) was activated during testing.

ing-type of behaviour without any residual deformations in the adhesive joint and the timber frame. A ductile fail- ure mechanism (1) was established in the steel holddowns. It should be noted that a low vertical load on the bracing walls had an influence on the development of a rocking mechanism. With a higher vertical load the shear behaviour of the glass panels would be activated, hence increasing the stresses in the shear brackets, the adhesive and the glass.

\section{CONCLUSIONS}

Four single-story and four two-story timber-glass structures combining different types of timber-frame wall elements with fixed glazing were tested. The tested specimens exhibited a rocking type of behaviour, dissipating the seismic energy in the corner hold-downs. The shear slip of the panels in the ground floor was minimal. The shear slip in the adhesive line was present however no damage occurred.

The experimental results present a good starting point for a future parametric FEM study. The latter will provide a more comprehensive understanding of the influ- 
ence that different types and dimensions of the glazing and different types of adhesives have on the seismic response of timber-glass structures.

\section{ACKNOWLEDGEMENTS}

The support of the companies Gozdno gospodarstvo Slovenj Gradec, Reflex, Kager hisa, Ko-glas, Kömmerling, Rothoblaas and Storaenso who donated the materials needed for the experiments is gratefully acknowledged. The research support provided by the EU through the European Social Fund "Investing in your future" is also acknowledged.

\section{REFERENCES}

[1] Niedermaier, P. (2003) Shear-strength of glass panel elements in combination with timber frame constructions. Proceedings of the 8th International Conference on Architectural and Automotive Glass (GPD), Tampere, 15-18 June 2003, 262-264.

[2] Kreuzinger, H. and Niedermaier, P. (2005) Glas als Schubfeld. Tagungsband Ingenieurholzbau, Karlsruher Tage.

[3] Holzforshung Austria (2008) Holz-glas-verbundkonstruktionen, weiterentwicklung und herstellung von holzglas-verbundkonstruktionen durch statisch wirksames verkleben von holz und glas zum praxiseinsatz im holzhausbau (impulsprojekt V2 des kind holztechnologie). Endbericht, Vienna.

[4] Cruz, P., Pequeno, J., Lebet. J.P. and Močibob, D. (2010) Mechanical modelling of in-plane loaded glass panes. Challenging Glass 2-Conference on Architectural and Structural Applications of Glass, Delft, 20-21 May 2010, 309-319.

[5] Blyberg, L. (2011) Timber/glass adhesive bonds for structural applications. Licentiate Thesis by Louise Blyberg, Linnaeus University, School of Engineering, Sweden.

[6] Ber, B., Premrov, M. and Kuhta, M. (2012) Horizontal load-carrying capacity of timber-framed walls with glass sheathing in prefabricated timber construction. Proceedings of the 34th Assembly of Structural Engineers of Slovenia, Bled, 11-12 October 2012, 211-218.

[7] Schober, K.P., Leitl, D. and Edl, T. (2006) Holz-glasverbundkonstruktionen zur gebäudeaussteifung, magazin für den holzbereich. Heft 1, Holzforschung Austria, Vienna.

[8] Wellershoff, F. (2006) Nutzung der verglasung zur aussteifung von gebäudehüllen. Ph.D. Thesis, SchriftenreiheStahlbau RWTH Aachen, Heft 57, Shaker Verlag, Aachen.

[9] Mocibob, D. (2008) Glass panel under shear loadingUse of glass envelopes in building stabilization. Ph.D. Thesis, École Polytechnique Fédérale de Lausanne, Thèse
No. 4185, Lausanne.

[10] Huveners, E.M.P. (2009) Circumferentially adhesive bonded glass panes for bracing steel frames in facades. Ph.D. Thesis, University of Technology Eindhoven, Eindhoven.

[11] Rajcic, V. and Zarnic, R. (2012) Racking performance of wood-framed glass panels. The future of timber engineering. World Conference on Timber Engineering, Auckland, 15-19 July 2012, 57-56.

[12] Rajcic V. and Zarnic R. (2012) Seismic response of timber frames with laminated glass infill. Proceedings of the 45th CIB-W18 Meeting, August 2012, Växjö, Paper 4515-4.

[13] Zegarac L.V. and Premrov, M. (2011) An approach in architectural design of energy-efficient timber buildings with a focus on the optimal glazing size in the south-oriented façade. Energy and Buildings, 43, 3410-418. doi:10.1016/j.enbuild.2011.09.003

[14] Kozem S.E., Premrov, M. and Silih, S. (2012) Numerical analysis of timber-framed wall elements coated with single fibre-plaster boards. Engineering Structures, 41, 118125. doi:10.1016/j.engstruct.2012.03.044

[15] Dujic B., Aicher S. and Zarnic R. (2006) Testing of wooden panels applying realistic boundary conditions. WCTE 2006-9th World Conference on Timber Engineering, Portland, 6-10 August 2006, 193 Pages.

[16] Dujic, B., Klobcar, S. and Zarnic, R. (2007) Influence of openings on shear capacity of wooden walls. Proceedings of the 40th CIB-W18 Meeting, Bled, Paper 40-15-6.

[17] Yasumura, M. (1986) Racking resistance of wooden frame walls with various openings. Proceedings of the 19th CIB-W18 Meeting, Florence, 25 Pages.

[18] Standards New Zealand (1993) Timber structures standard. NZS3603, Wellington.

[19] Hoadley, R.B. (2000) Understanding wood, a Crafstman`s guide to wood technology. The Taunton Press, Newtown and Naugatuck.

[20] European Committee for Standardization (2011) EN 594: 2011: Timber structures. Test methods. Racking strength and stiffness of timber frame wall panels. Brussels.

[21] European Committee for Standardization (2003) EN 1194: 2003 E: Timber structures. Glued laminated timber. Strength classes and determination of characteristic values. Brussels.

[22] European Committee for Standardization (2004) EN 5721:2004: Glass in building. Basic soda lime silicate glass products. Part 1: Definitions and general physical and mechanical properties. Brussels.

[23] F\&E Kömmerling Chemische Fabrik GmbH (2011) Stresselongation-curve for Ködiglaze P/Ködiglaze P hv. Germany (Stress-strain diagram-Figure 5 on page 4 ). 